\title{
Association of Histological Findings with Tc-99m Sestamibi Parathyroid Imaging in Hyperfunctional Parathyroid Gland
}

\author{
Hosne Ara Rahman ${ }^{1}$, Jasmine Ara Haque², Waseka Akhter Jahan ${ }^{3}$, Sabina Jesmin ${ }^{4}$ \\ ${ }^{1}$ Principal Medical Officer \& Associate Professor, Institute of Nuclear Medicine and Allied Science, Mitford Hospital, \\ Dhaka, Bangladesh; ${ }^{2}$ Chief Medical Officer \& Professor, National Institute of Nuclear Medicine and Allied Science, \\ BSMMUH, Dhaka, Bangladesh; ${ }^{3}$ Associate Professor, Department of Biochemistry, National Institute of \\ Neurosciences \& Hospital, Dhaka, Bangladesh; ${ }^{4}$ Assistant Professor, Department of Pharmacology, \\ National Institute of Neurosciences \& Hospital, Dhaka, Bangladesh
}

[Received: January 2015; Revised: March 2015; Accepted: June 2015; Published: January 2016]

\begin{abstract}
Background: Hyperthyroidism is a relatively common disorder that results from increased production of parathormone. Tc-99m sestamibi (MIBI) scanning is used for localization of abnormal parathyroid gland, with high reported sensitivities. However, there exists a group of patients in whom MIBI scan is either equivocal or negative. Objectives: The aim of this study was to see association of the histological features of pathologic parathyroid gland with MIBI scan in hyperfunctional parathyroid gland. Methodology: This retrospective study was conducted with primary hyperthyroidism who underwent MIBI scan. The data were collected from the record from January 2012 to December 2014 for a period of two years. All patients underwent parathyroid surgery followed by histopathological examination. According to oxyphil cell distribution patients are divided in three groups. Group I comprised of $>25.0 \%$ oxyphil cell; group II included the 25 to $75 \%$ oxyphil cell and group III included $>75 \%$ of oxyphil cell. Result: A total 56 patients with hypercalcaemia and high serum parathyroid hormone (PTH) level were studied. Mean age was $41.3( \pm 19.8)$ years with a range of 21 to 63 years. MIBI scan was true positive in $34(60.7 \%)$ cases and false negative in $22(39.3 \%)$ cases. In group I MIBI scan was true positive in $4(36.3 \%)$ cases and false negative in $7(63.7 \%)$ cases. In group II MIBI scan showed positive in $17(62.9 \%)$ cases and negative in $10(37.1 \%)$ cases. In group III out of 18 patients $13(72.2 \%)$ showed MIBI scan positive whereas, $5(27.8 \%)$ showed negative scan. The sensitivity was $36.3 \%$ in group I whereas, $62.9 \%$ and $72.2 \%$ in group II and group III respectively. Conclusion: Based on these findings, it could be say that Tc-99m setamibi uptake correlate with parathyroid oxyphil cell content, and false negative scan can occur with parathyroid glands containing predominantly clear cell. [Journal of National Institute of Neurosciences Bangladesh, 2016;2(1):14-18]
\end{abstract}

Keywords: Hyperparathyroidism; Tc-99m sestamibi (MIBI) scan; oxyphil cell; parathormone; hyperfunction

Correspondence: Dr. Hosne Ara Rahman, Principal Medical Officer, Institute of Nuclear Medicine and Allied Science, Mitford Hospital, Dhaka, Bangladesh; Email : dr_anunmc07@yahoo.com; Cell no.: +8801712984900

Conflict of interest: There is no conflict of interest to any of the authors of this article.

Funding agency: This research work was performed by own cost.

Contribution to authors: HAR \& JAH were contributed from protocol preparation up to report writing. WAJ was prepared the manuscript and was revised the manuscript.

How to cite this article: Rahman HA, Haque JA, Jahan WA. Association of Histological Findings with Tc-99m Sestamibi Parathyroid Imaging in Hyperfunctional Parathyroid Gland. J Natl Inst Neurosci Bangladesh, 2016;2(1): 14-18

Copyright: (02016 Rahman et al. Published by Journal of National Institute of Neurosciences Bangladesh. This article is published under the Creative Commons CC BY-NC License (https://creativecommons.org/licenses/by-nc/4.0/). This license permits use, distribution and reproduction in any medium, provided the original work is properly cited, and is not used for commercial purposes.

\section{Introduction}

Primary hyperparathyroidism is a common endocrine disorder. With the increase of biochemical screening even asymptomatic primary hyperparathyroidism is diagnosed. Of all available imaging modalities Tc- $99 \mathrm{~m}$ sestamibi scanning has become the modality of choice as compared to other imaging modalities such as ultrasonography, CT and MRI. The reported sensitivity 
of MIBI scan is $74 \%-90 \%$ and specificity is $75 \%$ to $95.0 \%{ }^{1}$. In spite of that a substantial number of patients with elevated PTH level may have false negative sestamibi scan. In these cases, no adenoma / hyperplasia are visualized on the scan although; the patient may have parathyroid pathology leading to diagnostic dilemma. In cases where sestamibi scans fail to detect any abnormal parathyroid gland, it has been found that this radiotracer did not accumulate in parathyroid gland to a proper extent. In addition certain adenomatous glands are reported to have a markedly abnormal capacity for radiotracer efflux to the extra cellular compartment, which consequently causes the long standing retention of radiotracer to the parathyroid gland ${ }^{2}$. As tracer accumulation \& retention is essential for nuclear imaging the aim of this study is to see whether the histological features of pathologic parathyroid gland have any impact on MIBI scan.

\section{Methodology}

This was a retrospective study of 56 patients with primary hyperparathyroidism referred to the department for Tc-99m sestamibi parathyroid scanning between January 2012 to December 2014. Diagnostic criteria for primary hyperparathyroidism were based on high PTH level associated with hypercalcemia. In this study normal reference range for serum PTH was 9-80 $\mathrm{pg} / \mathrm{mL}$ and serum calcium was $8.1-10.3 \mathrm{mg} / \mathrm{dL}$. The dual- phase method of parathyroid imaging was conducted using standard protocol. All patients received $20 \mathrm{mCi}$ Tc-99m sestamibi intravenously. Early phase (20-minutes post injection) and delayed phase (2-hour post injection) SPECT images were acquired on a dual head SPECT/CT system (Symbia, Siemens). The images were acquired into a $128 \times 128$ matrix with $30 \mathrm{sec}$ per step having 60 steps over a fall $360^{\circ}$ orbit. In delayed view a low dose CT was also performed covering the area of SPECT acquisition. Images were reconstructed in transverse, coronal and sagittal view. Sestamibi scan were designated as either 'positive' or 'negative'. A positive scan was defined when an area of relatively increased radiotracer uptake in early phase persisted and became more prominent in delayed phase because of slower washout of radiotracer from parathyroid than from thyroid gland. Conversely negative scan was considered when delayed images show no unusual activity in the neck region. All patients underwent surgery followed by histopathological confirmation. The sections of all parathyroid specimens were evaluated by a single pathologist who was blinded to the results of sestamibi scans. The histopathological finding included cellular architecture, cell type and fat content. The cellular composition was assessed relative to all parathyroid cells present, regardless of fat content. The architectural grade of I to III reflect the predominance of oxyphil cell Vs chief cell content. Grade I represent $<25 \%$, grade II 25 to $75 \%$ and grade III represent $>75 \%$ of oxyphil cell. All quantitative data expressed as mean $\pm \mathrm{SD}$. Statistical analysis was performed using SPSS software version 15 . $P$ value $<0.05$ was considered statistically significant.

\section{Results}

A total 56 patients with hypercalcaemia and high serum PTH level were studied. Mean age was $41.3 \pm 19.8$ years (range 21 to 63 years). Female were predominant than male which was $32(57.2 \%)$ and $24(42.8 \%)$ respectively (Table 1).

Table 1: Demographic of the Study Population $(n=56)$

\begin{tabular}{ll}
\hline Variables & Values \\
\hline Mean age \pm SD (Range) & $41.3 \pm 19.8(21$ to 63 years $)$ \\
\hline Gender & \\
- Male & $24(42.8 \%)$ \\
- Female & $32(57.2 \%)$ \\
\hline
\end{tabular}

MIBI scan was true positive in $34(60.7 \%)$ cases and false negative in $22(39.3 \%)$ cases. In group I ( $<25 \%$ oxyphil cell) among 11 patients MIBI scan was true positive in $4(36.3 \%)$ cases and false negative in $7(63.7 \%)$ cases. In group II ( 25 to $75 \%$ oxyphil cell) out of 27 cases MIBI scan showed positive in $17(62.9 \%)$ cases and negative in $10(37.1 \%)$ cases. In group III ( $>75 \%$ oxyphil cell) out of 18 patients $13(72.2 \%)$ showed MIBI scan positive whereas, $5(27.8 \%)$ showed negative scan (Table 2).

Table 2: Histopathological Distribution of Oxyphil Score among True Positive and False Negative Scan Group

\begin{tabular}{lcccc}
\hline $\begin{array}{l}\text { Oxyphil } \\
\text { cell distribution }\end{array}$ & $\begin{array}{c}\text { True } \\
\text { Positive }\end{array}$ & $\begin{array}{c}\text { False } \\
\text { Negative }\end{array}$ & Total & Pvalue \\
\hline Less than 25\% ( Group-I) & 4 & 7 & 11 & \\
25 to $75 \%$ ( Group II) & 17 & 10 & 27 & $<0.05$ \\
More than 75\% (Group III) & 13 & 5 & 18 & \\
\hline Total & $\mathbf{3 4}$ & $\mathbf{2 2}$ & $\mathbf{5 6}$ & \\
\hline
\end{tabular}

The sensitivity was $36.3 \%$ in group I whereas, $62.9 \%$ and $72.2 \%$ in group II and group III respectively (Table 3 ). 
Table 3: Sensitivity of the MIBI

\begin{tabular}{|c|c|c|c|}
\hline \multirow{2}{*}{$\begin{array}{l}\text { Variables } \\
\text { Group -I }\end{array}$} & \multicolumn{2}{|l|}{ Values } & $95 \% \mathrm{CI}$ \\
\hline & Sensitivity & $36.3 \%$ & $10.9 \%$ to $69.2 \%$ \\
\hline & Positive Likelihood Ratio & 0.36 & \\
\hline & Accuracy & $36.3 \%$ & \\
\hline & Z statistic & 8.2 & \\
\hline Group II & Sensitivity & $62.9 \%$ & $42.3 \%$ to $80.6 \%$ \\
\hline & Positive Likelihood Ratio & 0.63 & \\
\hline & Accuracy & $62.9 \%$ & \\
\hline & Z statistic & 22.8 & \\
\hline Group III & Sensitivity & $72.2 \%$ & $46.5 \%$ to $90.3 \%$ \\
\hline & Positive Likelihood Ratio & 0.72 & \\
\hline & Accuracy & $72.2 \%$ & \\
\hline & Z statistic & 21.5 & \\
\hline
\end{tabular}

\section{Discussion}

Tc-99m sestamibi (MIBI) is currently the most popular agent for detecting hyperfunctioning parathyroid tissue. When it is used for pre operative localization of parathyroid adenoma, it help the surgeons and contributed to the widespread use of minimally invasive procedures that lowering morbidity and mortality rates $^{2-3}$. Sestamibi is a lipophilic cation that diffuses passively down an electro-chemical gradient through cell membrane and accumulates almost exclusively in mitochondria of parathyroid lesion ${ }^{4}$. Based on this assumption, MIBI uptake within the parathyroid gland could be related to cell types like chief cells with high metabolic activity and/or oxyphil cell with many mitochondria. However, clear cell and adipose cell thought to have no significant role in MIBI uptake ${ }^{5-6}$.

In this study the overall sensitivity of MIBI scan was $67.2 \%$ which is low compare to other reported sensitivity of $75-80 \%{ }^{1}$. In cases where sestamibi scan fail to detect the parathyroid tissue, it has been found that the radiotracer did not accumulate in the tissue properly. As already mentioned oxyphil cell possess a higher mitochondrial content than either thyroid or adjacent tissue so, oxyphil cell predominance play a greater role in metabolic activity and hence radiotracer uptake. In the present study in group I among 11 patients MIBI scan is true positive in 4 cases and false negative in 7 cases. In group II out of 27 cases MIBI scan show positive in 17 cases and negative in 10 cases. In group III out of 18 patients 13 shows MIBI scan positive whereas, 5 show negative scan. The sensitivity is $36.3 \%$ in group I whereas, $62.9 \%$ and $72.2 \%$ in group II and group III respectively. In this study sensitivity of higher oxyphil content group is more or less consistent with other reported sensitivities.

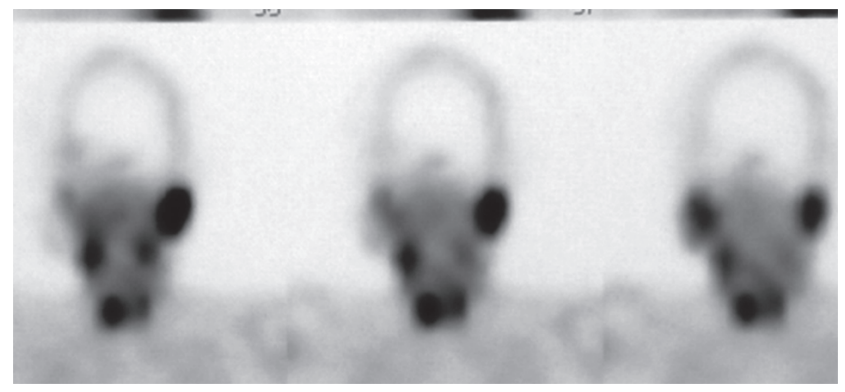

Figure Ia: Post 20 minutes view (early phase)

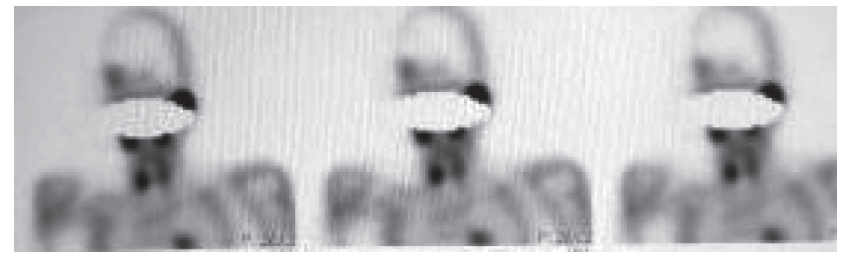

Figure Ib: Post 2 hour view (delayed phase)

Figure I: Tc-99m MIBI Scan Showing Positive Result for Parathyroid Adenoma/Hyperplasia

One study by Takebayashi et $\mathrm{al}^{7}$ compared 11 negative MIBI scan with 61 positive scan and demonstrated a association between positivity of scan and oxyphil cell content. This is supported by Sandrock et $\mathrm{al}^{8}$ study where the authors have demonstrated the ratio of oxyphil and clear cell when comparing true-positive versus false-negative MIBI scan. A ratio of oxyphil to clear cells of more than 1 was correlated with positive scan $^{8}$. As because clear cells have no known function and no significant metabolic activity, a review of several literatures showed large clear cell adenoma have little sestamibi uptake compare to oxyphil cell ${ }^{9-10}$. Same finding is shared by Carpentier et $\mathrm{al}^{11}$ who reported that a higher oxyphil content $(>25 \%)$ was associated with an increased late technetium uptake. Thompson et $\mathrm{al}^{12}$ also shared the same opinion, in their study only 2 among 20 false negative results exhibited greater than $25 \%$ oxyphil content. On the contrary there are several reports showing no relationship exist between oxyphil cell predominance and sestamibi scan interpretation though Westreich et $\mathrm{al}^{13}$, disagreed with this finding and in a study they showed an oxyphil content $>20 \%$ increased the rate of positive scan by 4 fold ${ }^{14-15}$. Moreover, not only the cell type Torregrosa et a ${ }^{16}$ speculated than false negative MIBI scan may be associated with the phases of cell cycle and higher degree of uptake is correlated with the G2/S active phase. 


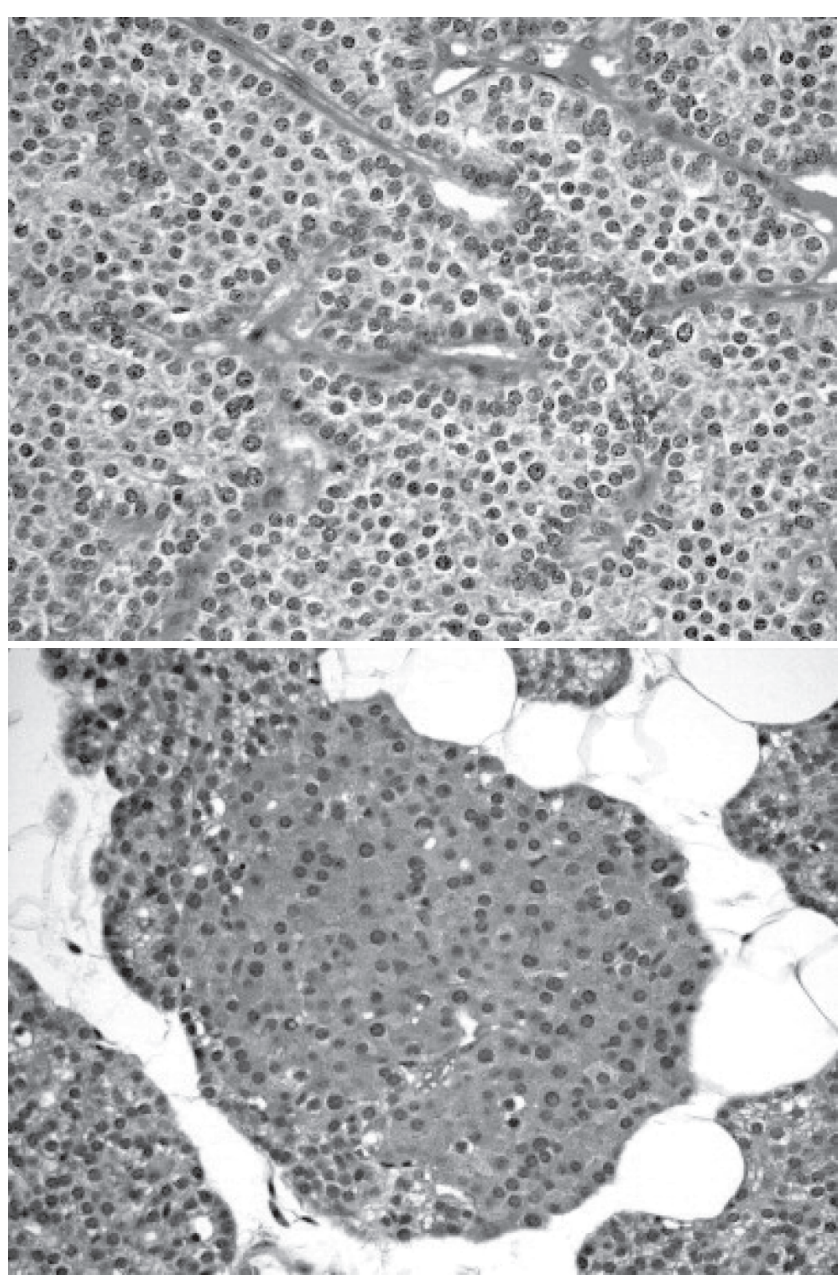

Figure III: Chief cell predominant Oxyphil cell predominant

According to some author parathyroid capsule examination is the preferred method of classic pathological diagnosis because it shows a sub-capsular rim of suppressed normal parathyroid cell. As parathyroid capsule is difficult to quantify and the entire specimen may not contain that aspect of parathyroid gland, in this study we did not consider this capsular pattern. Moreover, there are also other important factors that need to be taken into account when analyzing false negative MIBI result. Weight of the gland, parathormone level, expression of P-glycoprotein, serum calcium level, serum vitamin D level and use of calcium channel blocker may influence the MIBI uptake ${ }^{17-18}$.

The factors that affect sestamibi localization are still remains a debatable issue because no consensus opinion has been reached yet. A larger series of parathyroid study is necessary to achieve the end. However, one of the important findings of this study is that regardless of which of these factors is predominant, if a hyperparathyroid patient showing higher MIBI uptake the patient is suitable for surgery than medical therapy.

\section{Conclusion}

In conclusion diagnosis of primary hyperparathyroidism is based on clinical and biochemical parameter. There are so many factors that can influence the positivity of MIBI scan. Therefore by understanding the limitations of this modality clinician should take the therapeutic decision.

\section{References}

1. Mshelia DS, Hatutale AN, Mokgoro NP, Nchabaleng ME, Buscombe JR, Sathekge MM. Correlation between serum Calcium level and dual phase $99 \mathrm{~m} \mathrm{Tc}$-sestamibi parathyroid scintigraphy in primary hyperparathyroidism. Clin Physi Funct Imag 2011;32(11):19-24

2. Denhan DW, Normens J. Cost-effectiveness of pre-operative sestamibi scan for primary hyperparathyroidism dependent solely on surgeon's choice of operative procedure. J Am Coll Surg 1998; 186:293-314

3. Siegel A, Alvarado M ,Barsth Jr, Brady M, Lewis J. Parameter in prediction of the nuclear sensitivity of parathyroid scan. Clin Nucl Med 2006; 31:696-99

4. Parikshak M, Calciumstillo ED, Conrad MF, Talpos GB. Impact of hypercalcemia and PTH level in the sensitivity of preoperative sestamibi scan for primary hyperparathyroidism. Am Surg 2003; 69:393-98

5. Kannan S, Milas M, Neumann D, Parikh RT, Sipcerstein A, Licata A. Parathyroid nuclear scan: A focused review on technical and biological factors affecting its outcome . Clin Miner Bone Metab 2014; 11(1):25-30

6. Stawick SP, Chaar ME, Baillie DR, Jaik NP, Estrada FP. Correlation between biochemical testing pathology findings and preoperative sestamibi scans: a retrospective study of the minimally invasive radio guided parathyroidectomy approach. Nucl Med Review 2007;10:82-86

7. Takebayashi S,Hidai H, Chiba T,Takagi Y,Nafatani Y,Matsubara S. Hyperfunctional parathyroid gland with Tc-99m Mibi scan: semiquantitative analysis correlated with histologic findings. J Nucl Med 1999;40:1792-1797

8. Sandrock D, Merino M, Jeffrey N,Neumann R. Ultrastructural histology correlates with results of thallium-201/technitium-99m parathyroid subtraction scintigraphy. J Nucl Med 1993;34:24-29

9. Westerdahl J, Bergenflez A. Sestamibi scan directed parathyroid surgery: potentially high failure rate without measurement of intraoperative parathyroid hormone. World J Surg 2004: 1132-8

10. Cermik TF, Puyan FO, Sezer A, Firat MF, Berkarda S. Relation between Tc-99m sestamibi uptake and biological factors in hyperparathyroidism. Ann Nucl Med 2005; 19: 387-92

11. Carpentier A, Jeanotte S, Verreault J. Preoperative localization of parathyroid lesions in hyperparathyroidism: relationship between Tc99 MIBI uptake and oxyphil cell content. J Nucl Med 1998;39:1441-1444

12. Thompson GB, Mullan BP, Grant CS . Parathyroid imaging with technetium-99m sestamibi: an initial institutional experience. Surg 1994;11:6966-973

13. Westreich R, Brandwein M , Mechanick JL,Bergman DA, 
urken ML. Preoperative parathyroid localization: correlating false-negative technetium $99 \mathrm{~m}$ sestamibi scan with parathyroid disease. Laryngoscope 2002; 113:567-572

14. Yamaguchi S, Yachiku S. Morikawa M. Analysis of proliferative activity of the parathyroid gland using proliferating cell nuclear antigen in patients with hyperparathyroidism. J Clin Endocrinol Metab 1997;82:2681-2688

15. Hung GU, Wang SJ, LinWY. 99m Tc MIBI parathyroid scintigraphy and intact parathyroid hormone levels in hyperparathyroidism. Clin Nucl Med 2003;28:180-185
16. Torregrosa Jv, Fuster D, Ybarra J, Ortin J, Moreno A, Valveny N. Predicting the effect of intravenous calcitriol on parathyroid gland activity using double phase Tc99 sestamibi scintigraphy. Am J Kidney Dis 2004;44:476-480

17. Fukagawa M, Kitaoka M, Inazawa T, Kurokawa K. Imaging of the parathyroid in CRF: diagnostic andtherapeutic aspect. Curr Opin Nephrol Hypertens 1997;6:345-349

18. Melloul M, Paz A, Koren R, Cytron S, Feinmesser R, Gal R. $99 \mathrm{~m}$ Tc MIBI scintigraphy of parathyroid adenomas and its relation to tumor size and oxyphil cell abundance. Eur J Nucl Med 2001;28:209-213 